\title{
Children Behavior in The Classroom of Early Childhood Education in Yogyakarta
}

\author{
Ratna Dewi Nur'aini ${ }^{1}$ \\ ${ }^{I}$ Department of Architecture, Faculty of Engineering, Universitas Muhammadiyah Jakarta, Indonesia \\ ratnadewina@ftumj.ac.id; ratnadewina@gmail.com
}

\begin{abstract}
Every child has uniqueness includes the habit in the room, and how to respond to the setting of space. The child's movement in an area is related to space and time. Different child behaviors will produce different responses to space and time. Early childhood education is an essential early childhood to determine the development of children in the future. The objective of this research is to find out early childhood behavior in class settings and factors that influence it. The location of this research is PAUD Ratnaningsih in Yogyakarta, on main role central class. The technique of data collection was done by observation and interview. The method of observation is behavioral mapping focused on children motion. This is to describe the movement of children on the map, to identify the type and frequency of movement and to indicate the relation of action to the class setting, using the place centered mapping method. The results of this study suggest that the class setting in PAUD Ratnaningsih using a central system that every central consist of activity settings by a moving system. Early childhood cannot stay for a long time in every activity setting because feel bored, frequently move to other positions. Children cannot focus in a long time, behave aimlessly. External factors affect the child's behavior such as elements of space, the role of teacher, and the design of activity setting.
\end{abstract}

() 2018 IJBESR. All rights reserved.

Keywords: activity setting, behavioral mapping, central system, early childhood education, place centered mapping.

\section{Introduction}

The child's movement in space is related to space and time. Different children's motion will produce different responses to space and time that surround it. Early age is an essential age in determining the formation of character and personality and the development of intelligence. Various research results concluded that the developmental period in early childhood significantly affects at the next stage until adulthood. Developmental psychologists call the period of children as a golden age that only comes once and can not be repeated.
Early childhood education is very basic and very decisive development of children in the future. The success of education in efforts to educate the life of the nation based on morals and noble morals is very dependent on the implementation of early childhood education. The curriculum used in early childhood education is the approach of Beyond Centers and Circle Times (BCCT) which is translated into the Indonesian language of "Sentra dan Lingkaran" approach. According to Handoko (2008), BCCT is considered the most ideal applied in Indonesia because it can stimulate all aspects of child intelligence (multiple intelligence) through directional play. Learning settings can encourage children to be active, creative, and keep thinking about digging their own experiences. 
PAUD Ratnaningsih is an institution of early childhood education located in Bantul Yogyakarta. The institute was established in 1997 and consisted of Baby Care (Taman Pengasuhan Anak), Play Group (Kelompok Bermain), and Kindergarten (Taman KanakKanak). PAUD Ratnaningsih has been accredited by National Accreditation Board of Non-Formal Education (BAN-PNF). The curriculum applied in this institution is the approach of Beyond Centers and Circle Times (BCCT).

Space is the smallest built-in environment system that is so important, especially as most of the time modern humans spend much time in it. In the study of environmental and behavioral architecture, space is defined as a plot bounded by walls and roofs by either permanent or non-permanent elements. In relation to humans, the most important thing about the influence of space on human behavior is the function or usage of that space. Components of space are fixed such as walls, columns, and roof, semi-fixed such as furniture; or non-fixed such as color and decoration (Rapoport, 1982).

According to Moore (in Purwaningrum, 2006), children have their own perceptions of space in their schools, where there are two types of school plans: open floor plan and traditional classrooms (covered plans with multiple barriers, and rigid furniture layouts). Schools with open plans are also called schools without walls, a concept of planning, with centers of activity that are open in terms of visual and circulation lines of view. In open-plan schools, children have many learning zones, meet more teachers, and work in a wider variety of group sizes. Children have more understanding of the whole school.
Space is defined as the unlimited space, where everything exists, while the motion is defined as the transition of place or position, so that space in this research can be interpreted as the pattern and the magnitude/ dimension generated by the motion.

Place ballet (Seamon, 1979) can be used to describe the regularity of places in the habit, routine, and impulse of the physical environment. The behavior of a person in a certain space, by Seamon (1979) mapped in a place ballet, which can apply both indoor and outdoor. With place ballet will be developed to see more phenomenon of spatial behavior.

The National Education System Act affirms that early childhood education is a coaching effort aimed at children aged 0-6 years conducted through the provision of educational stimuli to assist growth and physical and spiritual development so that children have readiness in entering more education continue.

According to Harizal (2008), responding the development of early childhood needs an education program designed with the level of child development. We need to design the classroom into play area, singing, moving freely, we make the classroom as a creativity area for children and make them feel at home and psychologically comfortable.

The BCCT curriculum approach focuses on children. The learning is centered in the center of play and the child is in a circle. The play center is a zone or play area with a set of equipment that serves as an environmental foothold needed to support children's development in three types of games, namely 
sensorimotor play (functional), role play, and development play. While the circle is when educators sit with children in a circular position to provide a foothold to children who do before and after playing (Handoko, 2008).

The learning process using the BCCT approach focuses on seven activities, namely: (1) arrangement of the main environment, educators prepare 3-5 settings of activities equipped with materials and equipment, (2) children welcome, (3) main opening, (4) transition, 5) core activities, (6) eating lunch together, and (7) closing activities. Evaluation activities are focused on program evaluation and evaluation of child development progress.

The objective of this research is to find out early childhood behavior in class settings and factors that influence it.

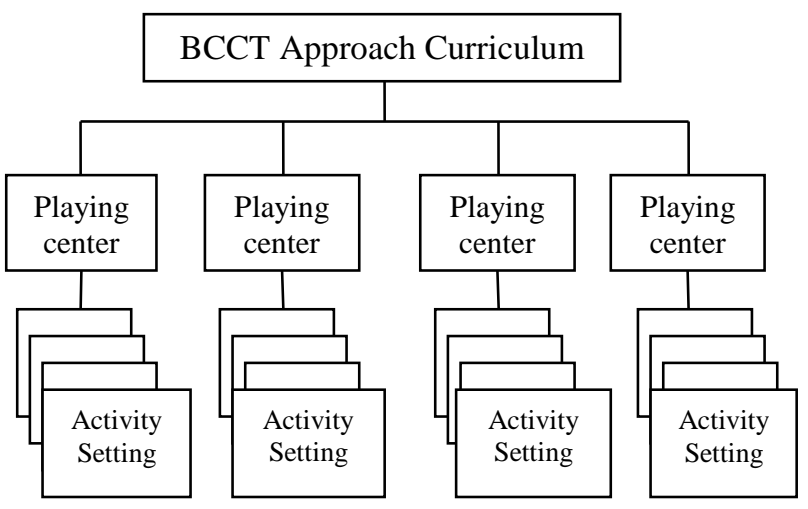

Figure 1. Spatial Diagram of BCCT Approach Curriculum

\section{Material and Methods}

The object of this research is the children motion in the classroom while doing the learning activities. The location of research is the center of classroom in Playgroup Ratnaningsih.
Cases in this study were three children in each group who move actively with the assumption that the children will generate more frequency of motion. The children were observed while doing the activities of learning center time.

This research was done by direct observation to the field and conducting direct interviews with institutional manager and teachers. Observation was done in the classroom / learning center by observing the children's behavior when the learning process took place. One of the methods used in the observation was behavioral mapping, which was the spatial-related behavioral mapping, especially the children's movement over a period of time. The purpose was to describe the children's motion in the seting, to identify the type and frequency of motion and to show the relationship of the motion with the form of the setting of the environment. This study used the method of person centered mapping, was a technique that emphasizes the movement of humans at a certain period of time (Haryadi, 1995). Activities of children in one class / center observed, recorded, and recorded images in one period.

The children motion data from each group in the observed class/center was analyzed by the factors that influenced it, then compared with the other classes / centers. The process of analysis was carried out continuously in the process of data collection.

\subsection{Description of Center}

The center in this research was the learning center classes in Play Group Ratnaningsih 
which consists of four classes / centers, namely:

1) Natural Material Center

2) Role Playing Center

3) Preparation Center

4) Development Center

In four centers, the area used for teaching and learning activities to sit on the floor in order the children were more freely and comfortably in motion. The classroom / center was used interchangeably by groups of students according to the schedule of activities that have been arranged. Settings of educational game activities can be described in following figure:

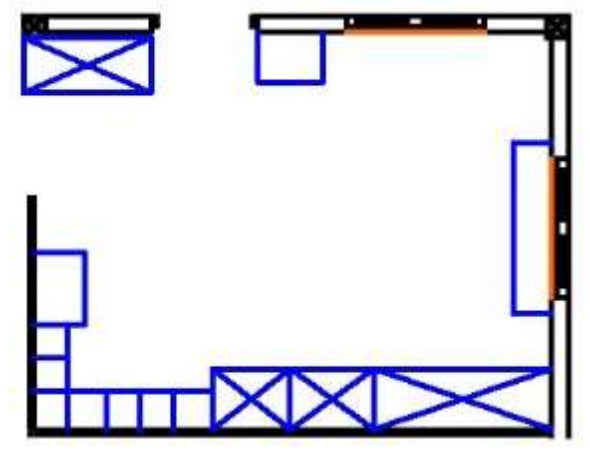

Figure 2. Class of Natural Material Center

Activity settings and tools used in Natural Material Center are: (I) Sawdust collage with picture paper, sawdust, and glue; (II) Arranging wood beads with wood beads, string, and little plate; (III) Banana leaf midrib stamp with paper, banana leaf midrib, coloring, and water; (IV) Counting gravel with gravel and little plates.

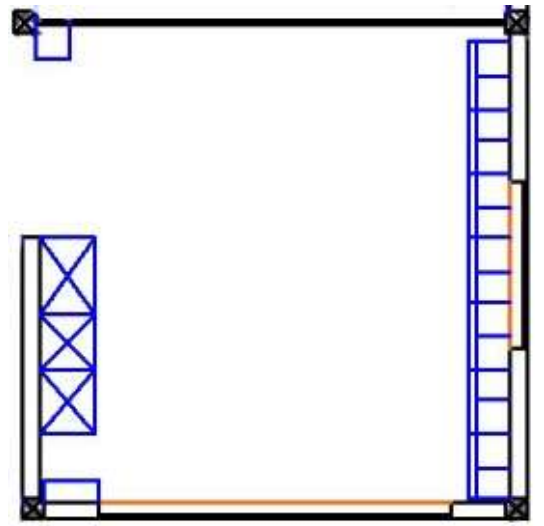

Figure 3. Class of Role Playing Center

Activity settings and tools used in Role Playing Center are: (I) Guard-house with guard-house replica, kentongan, sarung, and flashlight; (II) Restaurant with table, chairs, food replica, and cutlery; (III) Watching Television with television replica, table, chairs; (IV) Playing gamelan with little gamelan.

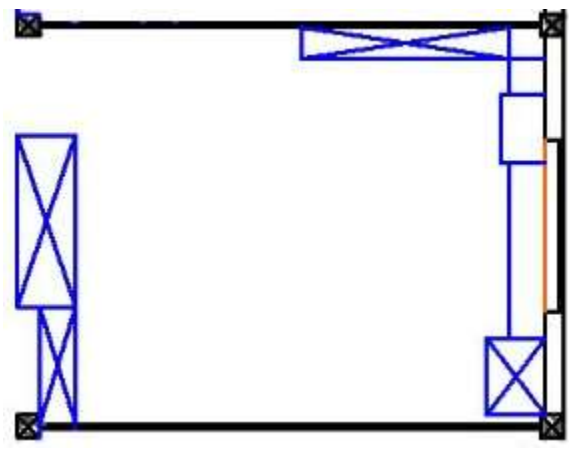

Figure 4. Class of Preparation Center

Activity settings and tools used in Preparation Center are: (I) Pieces of paper collage with picture paper, colored pieces of paper, and glue; (II) Arranging colored beads with colored beads and strings; (III) Reading picture book with picture book; (IV) Sticking letter with paper, letters, and glue. 


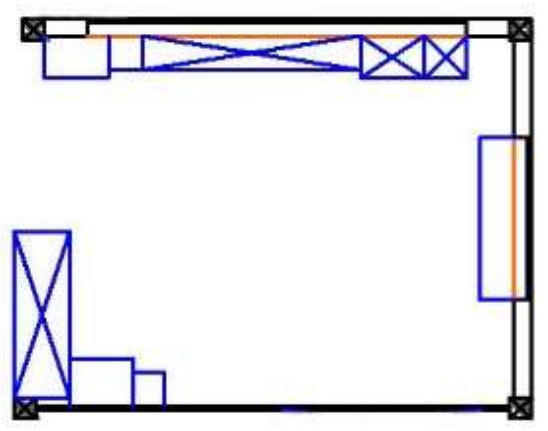

Figure 5. Class of Development Center

Activity settings and tools used in Development Center are: (I) Arranging blocks with blocks and accessories; (II) Drawing with paper and colored pastel; (III) Arranging lego with lego toys; (IV) Painting with pictured paper, water color, and paint brush.

\subsection{Description of Group}

The class / center group was differentiated by age. Each group was about 15-18 children. Student of Play Group consists of four groups: one group of 2-3 years old and three groups of 3-4 year olds. Each group was taught by two teachers. The division of classes / centers groups, namely:

1) Sunflower Group (Group 1) consists of 15 children aged 2-3 years.

2) Rose Group (Group 2) consists of 18 children aged 3-4 years.

3) Orchid Group (Group 3) consists of 18 children aged 3-4 years.

4) Waterlily Group (Group 4) consists of 18 children aged 3-4 years.

Everyday each center is entered by different groups by moving class method. One of the teacher follow her group to move every day, while the other teacher settled in a certain center.

Table 1. Case Research Description

\begin{tabular}{|c|c|c|c|}
\hline CASE & GENDER & GROUP & CENTER \\
\hline Case 1 & Female & \multirow{3}{*}{$\begin{array}{l}\text { Group } 1 \\
\text { (2-3 years old) }\end{array}$} & \multirow{3}{*}{$\begin{array}{l}\text { Natural } \\
\text { Material } \\
\text { Center }\end{array}$} \\
\hline Case 2 & Male & & \\
\hline Case 3 & Female & & \\
\hline Case 4 & Male & \multirow{3}{*}{$\begin{array}{l}\text { Group } 2 \\
\text { (3-4 years old) }\end{array}$} & \multirow{3}{*}{$\begin{array}{l}\text { Role } \\
\text { Playing } \\
\text { Center }\end{array}$} \\
\hline Case 5 & Male & & \\
\hline Case 6 & Female & & \\
\hline Case 7 & Male & \multirow{3}{*}{$\begin{array}{l}\text { Group } 3 \\
\text { (3-4 years old) }\end{array}$} & \multirow{3}{*}{$\begin{array}{l}\text { Prepara- } \\
\text { tion } \\
\text { Center }\end{array}$} \\
\hline Case 8 & Male & & \\
\hline Case 9 & Female & & \\
\hline Case 10 & Male & \multirow{3}{*}{$\begin{array}{l}\text { Group } 4 \\
\text { (3-4 years old) }\end{array}$} & \multirow{3}{*}{$\begin{array}{l}\text { Develop- } \\
\text { ment } \\
\text { Center }\end{array}$} \\
\hline Case 11 & Female & & \\
\hline Case 12 & Male & & \\
\hline
\end{tabular}

\section{Results and Discussions}

\subsection{Types of Activity}

The activities were observed in this study only focused during the teaching and learning activities in the classroom (indoor). In all cases, the schedule of teaching and learning activities in classroom took place at 07.30 11.00 am which were generally divided into three types of activities: private, classical, and individual with the following description:

1) Private activity is an activity conducted with face to face between teacher and student (one student is guided by one teacher) in turn. 

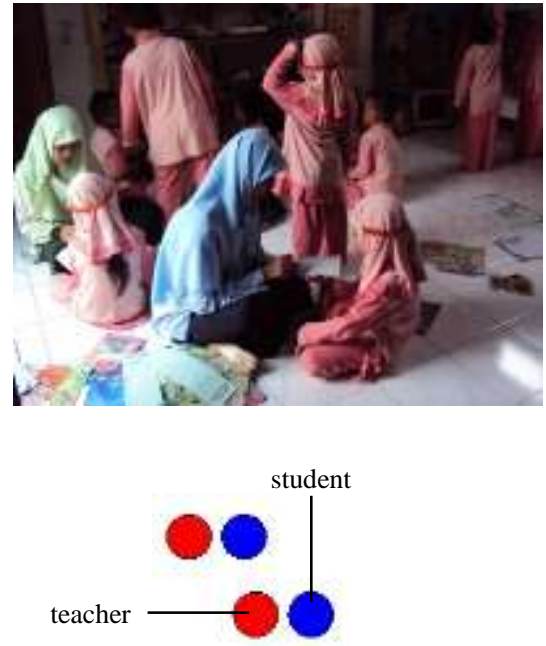

Figure 6. Private activity

2) Classical activity is an activity conducted jointly between teachers and students. This type includes daily prayer recitation, Al Qur'an and Hadith recitation, praying exercise, and eating snacks together. Teachers and student sit in a circle, the teachers give explanation to the students.
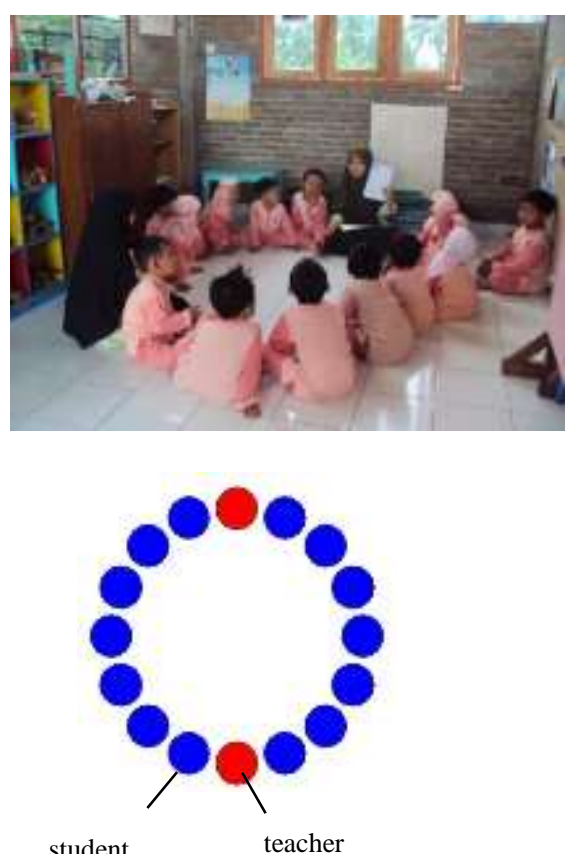

Figure 7. Classical activity (in a circle)
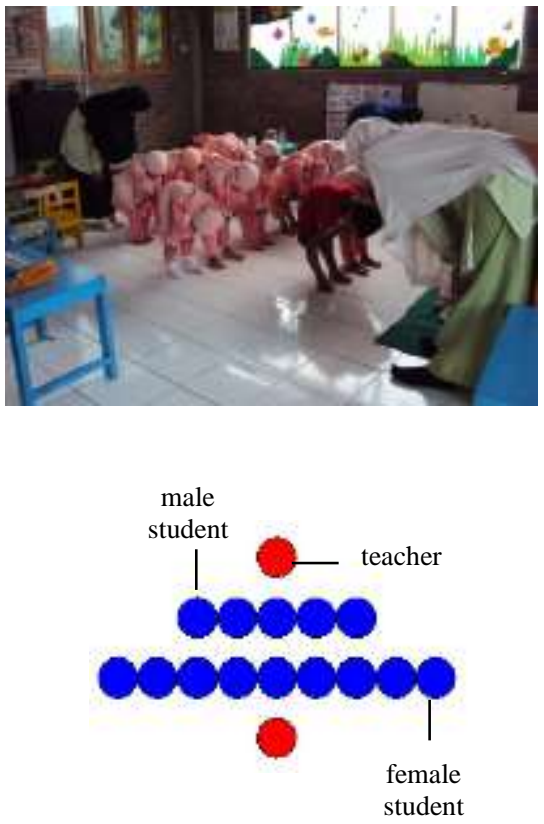

Figure 8. Classical activity (praying excercise)

3) Individual activity is an activity that is done individually according to desire and ability of student. In center, teachers prepare 4-5 settings of activities for students every day.

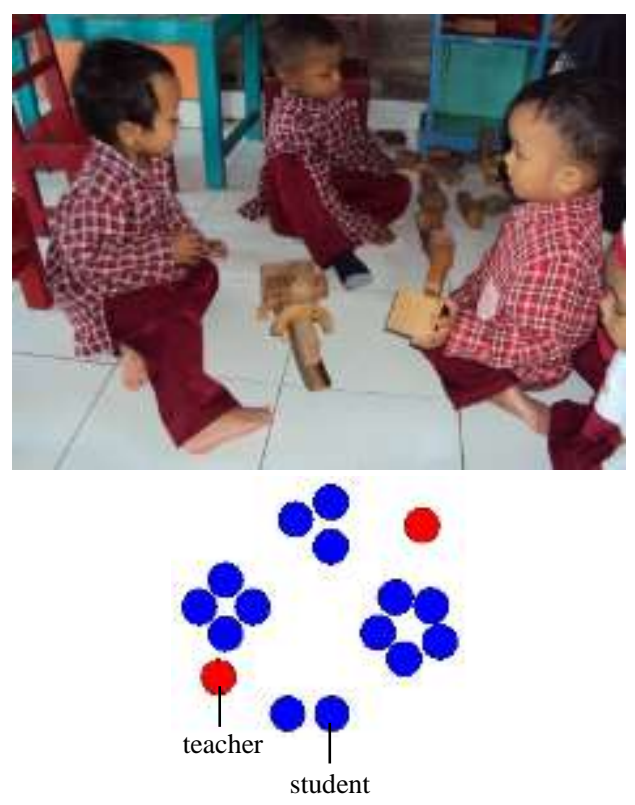

Figure 9. Individual activity 
Children were active in the activity settings that teachers prepared and moved from one setting to another.

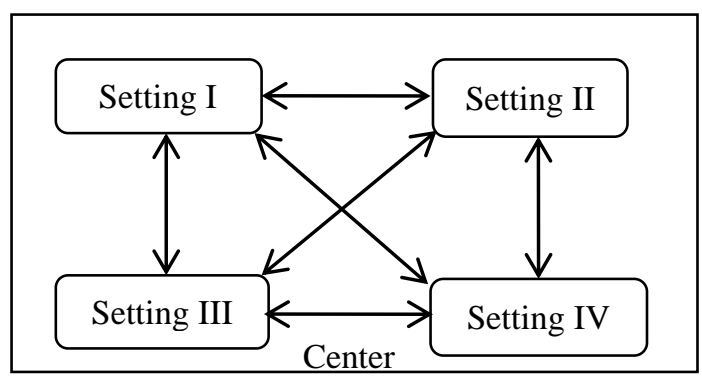

Figure 10. Children Interaction on Activity Settings

\subsection{Mapping of Children Motion}

Children motion mapping in classroom used person centered mapping method. Focus of observation were active children with assumption of high frequency motion, so maximum motion data will be generated. Observation focused on activities in center at 09.30-10.30 am.

Class of Natural Material Center has area $15,75 \mathrm{~m}^{2}$. In this class was set to 4 (four) activity settings:

(I) setting of collage activity with sawdust,

(II) setting of compose activity with woody beads,

(III) setting of stamp activity with banana leaf midrib,

(IV) setting of account activity with gravel.

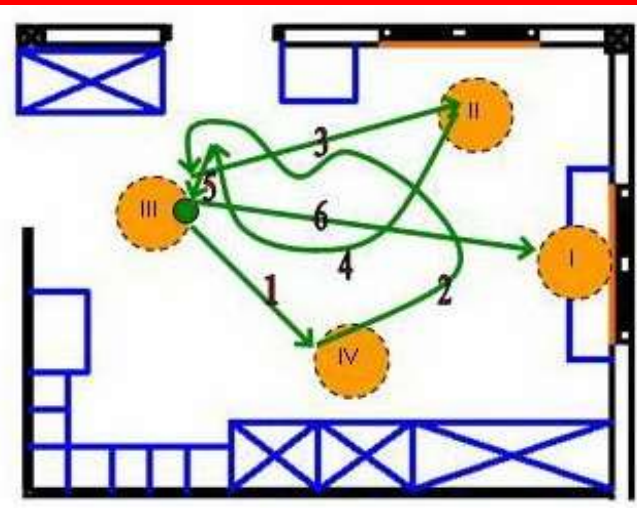

Figure 11. Behavioral Mapping of Case 1 (female student, 2 years old) in Natural Material Center

Case 1 (female student, 2 years old) in Natural Material Center had 6 motion flows. Tipe of motions were sitting, standing up, and walking. Her activities for one hour were:

a) She walked toward game setting,

b) She walked to look at other student's activity in game setting.

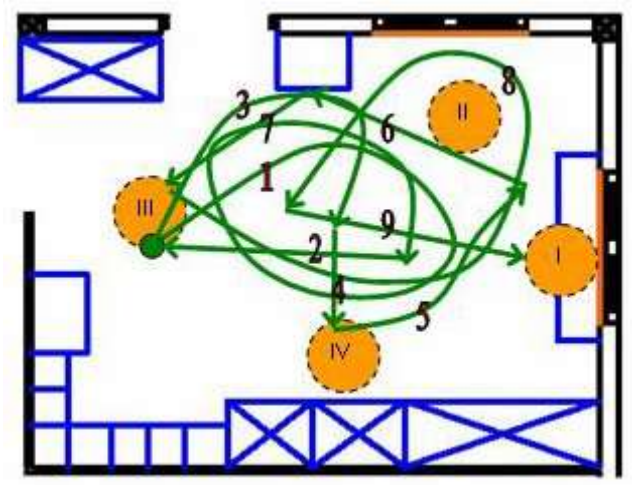

Figure 12. Behavioral Mapping of Case 2 (male student, 2 years old) in Natural Material Center

Case 2 (male student, 2 years old) in Natural Material Center had 9 motion flows. Tipe of motions were sitting, standing up, and walking. His activities for one hour were:

a) He walked toward game setting,

b) He walked to look at other student's activity in game setting,

c) He walked toward drinking bottle to drink, 
d) He walked around.

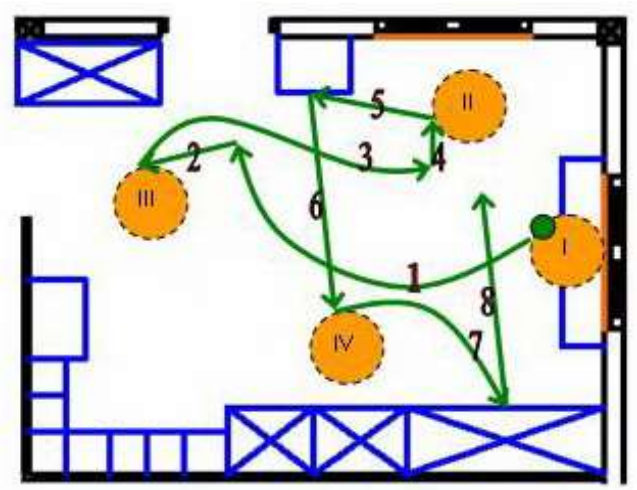

Figure 13. Behavioral Mapping of Case 3 (female student, 2 years old) in Natural Material Center

Case 3 (female student, 2 years old) in Natural Material Center had 8 motion flows. Tipe of motions were sitting, standing up, and walking. Her activities for one hour were:

a) She walked toward game setting,

b) She walked to look at other student's activity in game setting,

c) She walked toward drinking bottle to drink,

d) She walked toward her bag to take her toys,

e) She walks toward other student to play together.

Class of Role Playing Center has area area $20,25 \mathrm{~m}^{2}$. In this class was set to 4 (four) activity settings:

(I) setting of patrol station,

(II) setting of restaurant,

(III) seting of living room,

(IV) setting of gamelan show.

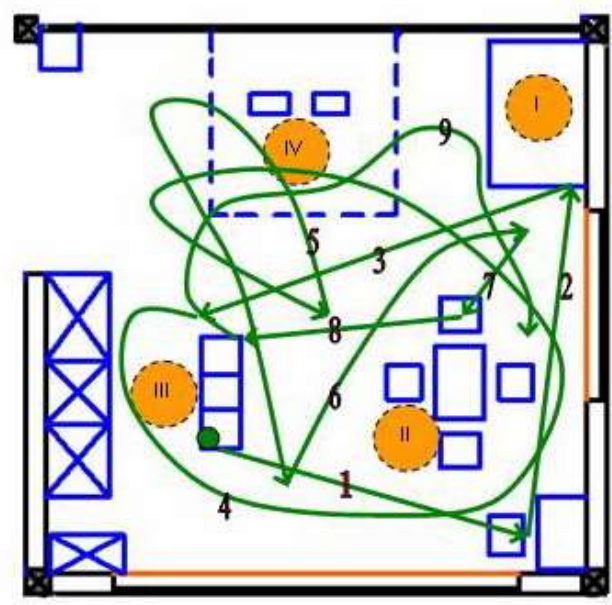

Figure 14. Behavioral Mapping of Case 4 (male student, 3 years old) in Role Playing Center

Case 4 (male student, 3 years old) in Role Playing Center had 9 motion flows. Tipe of motions were sitting, standing up, crawling, running, and walking. Roles: watching TV, chef, and patrol. Her activities for one hour were:

a) He crawled/walked/run toward game setting,

b) He walked to look at other student activity in game setting,

c) He walked,

d) He walked around to patrol,

e) He walked with a chair,

f) He run.

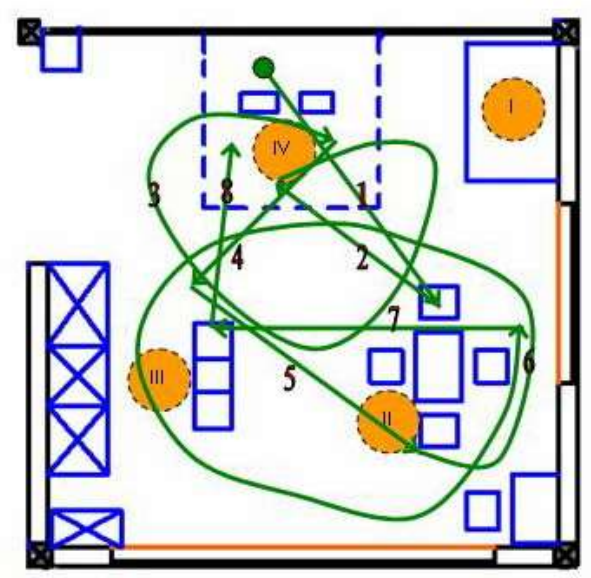

Figure 15. Behavioral Mapping of Case 5 (male student, 3 years old) in Role Playing Center 
Case 5 (male student, 3 years old) in Role Playing Center had 8 motion flows. Tipe of motions were sitting, standing up, running, and walking. Roles: gamelan player, buyer, and audience. His activities for one hour were:

a) He walked/run toward game setting,

b) He walked to look at other student activity in game setting,

c) He run around,

d) He walked around.

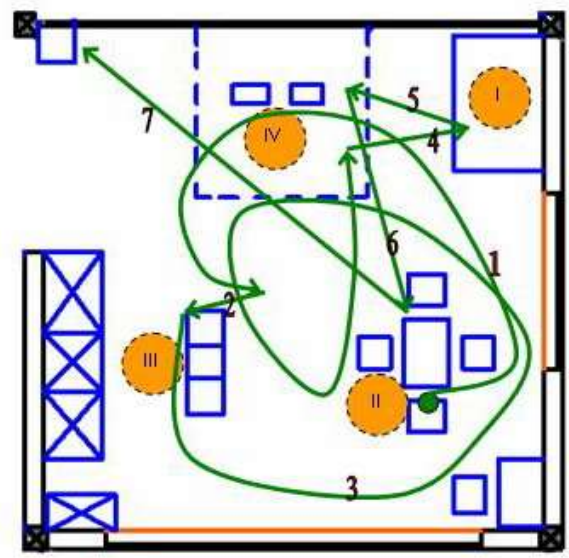

Figure 16. Behavioral Mapping of Case 6 (female student, 3 years old) in Role Playing Center

Case 6 (female student, 3 years old) in Role Playing Center had 7 motion flows. Tipe of motions were sitting, standing up, running, and walking. Roles: seller, watching television, and patrol.. Her activities for one hour were:

a) She walked/run toward game setting,

b) She walked to look at other student's activity in game setting,

c) She run toward drinking bottle to drink,

d) She run around.

Class of Preparation Center has area 15,75 $\mathrm{m}^{2}$. In this class was set to 4 (four) activity settings:
(I) setting of numbering collage made of paper,

(II) setting of compose activity with one color woody beads,

(III) setting of reading picture book,

(IV) setting of stick letters.

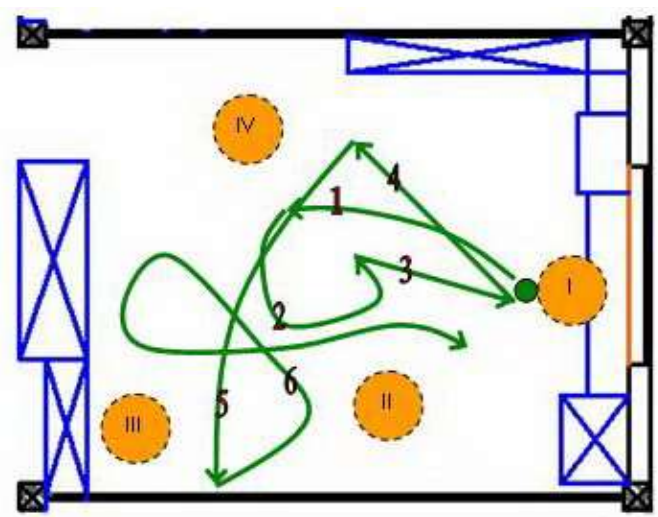

Figure 17. Behavioral Mapping of Case 7 (male student, 3 years old) in Preparation Center

Case 7 (male student, 3 years old) in Preparation Center had 6 motion flows. Tipe of motions were sitting, standing up, crawling, running, and walking. His activities for one hour were:

a) He walked toward game setting,

b) He crawled toward other student,

c) He played war game with other student,

d) He walked toward his teacher

e) He walked toward a picture board

f) He walked following other student. 


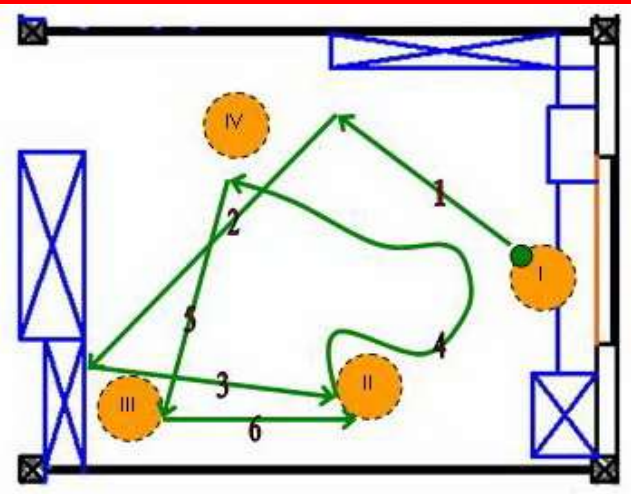

Figure 18. Behavioral Mapping of Case 8 (male student, 3 years old) in Preparation Center

Case 8 (male student, 3 years old) in Preparation Center had 6 motion flows. Tipe of motions were sitting, standing up, crawling, and walking. His activities for one hour were:

a) He walked then crawled toward game setting,

b) He walked to look at other student's activity in game setting,

c) He walked toward his teacher to show his creation,

d) He walked toward a rack to put his creation.

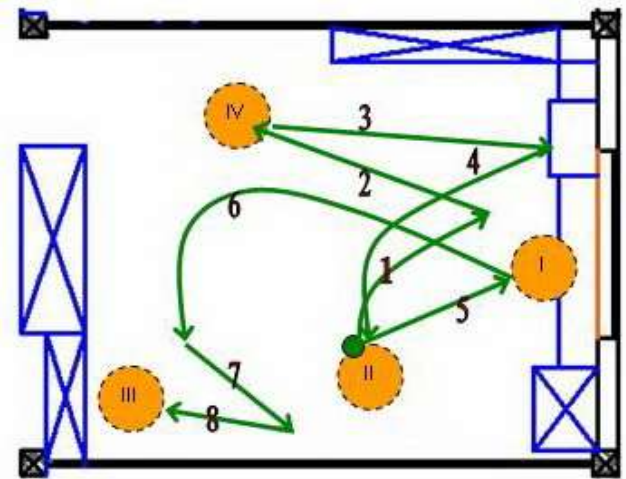

Figure 19. Behavioral Mapping of Case 9 (female student, 3 years old) in Preparation Center

Case 9 (female student, 3 years old) in Preparation Center had 8 motion flows. Tipe of motions were sitting, standing up, and walking. Her activities for one hour were:

a) She walked toward game setting, b) She walked to look at other student acvtivity in game setting,

c) She walked toward drinking bottle to drink,

d) She walked toward her teacher to ask something.

Class of Development Center has area 15,75 $\mathrm{m}^{2}$. In this class was set to 4 (four) activity settings:

(I) setting of blocks arrangement,

(II) setting of drawing with pastel,

(III) setting of lego toys,

(IV) setting of coloring with watercolor.

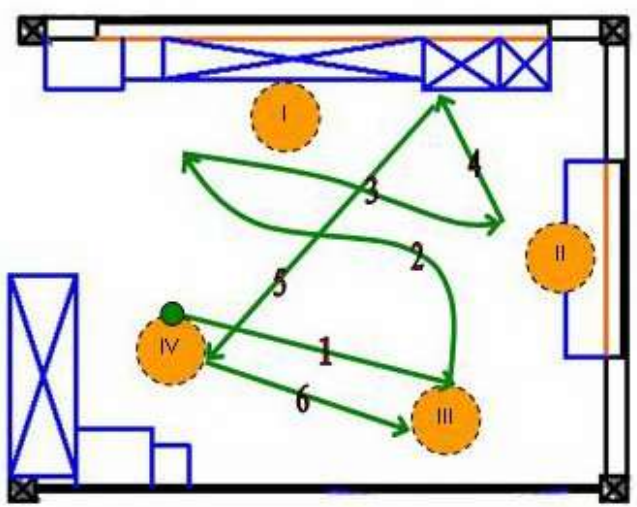

Figure 20. Behavioral Mapping of Case 10 (male student, 3 years old) in Preparation Center

Case 10 (male student, 3 years old) in Development Center had 6 motion flows. Tipe of motions were sitting, standing up, and walking. His activities for one hour were:

a) He walked toward game setting,

b) He walked to look at other student in game setting,

c) He walked toward toy rack,

d) He walked and carried paintbrush. 


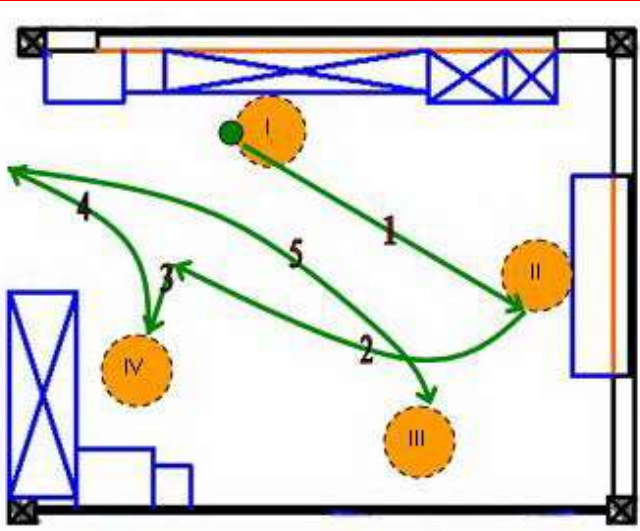

Figure 21. Behavioral Mapping of Case 11 (female student, 3 years old) in Preparation Center

Case 11 (female student, 3 years old) in Development Center had 6 motion flows. Tipe of motions were sitting, standing up, and walking. Her activities for one hour were:

a) She walked toward game setting,

b) She walked to look at other student's acvtivity in game setting,

c) She walked toward a door to look out.

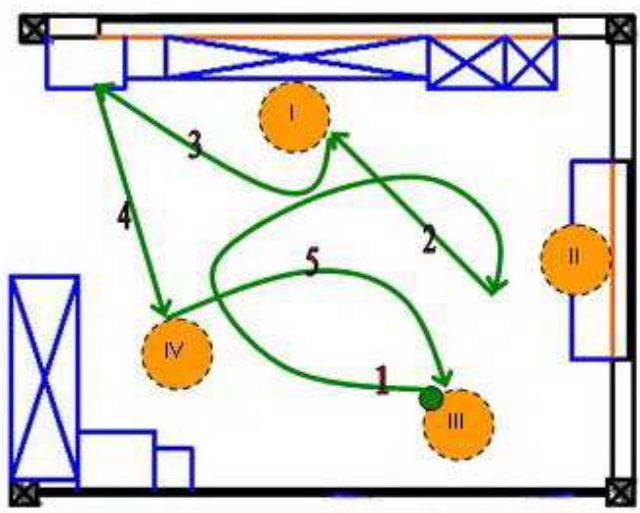

Figure 22. Behavioral Mapping of Case 12 (male student, 3 years old) in Preparation Center

Case 12 (male student, 3 years old) in Development Center had 5 motion flows. Tipe of motions were sitting, standing up, and walking. His activities for one hour were:

1) He walked toward game setting,

2) He walked to look at other student acvtivity in game setting,
3) He run toward drinking bottle to drink.

Observation result can be formulated kinds of children motions in learning center as follow:

Table 2. Classification of Children Motion

\begin{tabular}{|c|c|c|}
\hline $\mathrm{NO}$ & \multicolumn{2}{|l|}{ MOTION } \\
\hline \multirow{3}{*}{1.} & $\begin{array}{l}\text { Crawling toward game } \\
\text { setting }\end{array}$ & \multirow{3}{*}{$\begin{array}{l}\text { Moving } \\
\text { toward game } \\
\text { setting }\end{array}$} \\
\hline & Walking toward game setting & \\
\hline & Running toward game setting & \\
\hline \multirow{2}{*}{2.} & $\begin{array}{l}\text { Walking to look at other } \\
\text { student's activity at game } \\
\text { setting }\end{array}$ & \multirow{2}{*}{$\begin{array}{l}\text { Moving to } \\
\text { look at other } \\
\text { student's } \\
\text { activity in } \\
\text { game setting }\end{array}$} \\
\hline & $\begin{array}{l}\text { Crawling to look at other } \\
\text { student's activity at game } \\
\text { setting }\end{array}$ & \\
\hline \multirow{2}{*}{3.} & $\begin{array}{l}\text { Walking toward drinking } \\
\text { bottle to drink }\end{array}$ & \multirow{2}{*}{$\begin{array}{l}\text { Moving } \\
\text { toward } \\
\text { drinking } \\
\text { bottle to drink }\end{array}$} \\
\hline & $\begin{array}{l}\text { Running toward drinking } \\
\text { bottle to drink }\end{array}$ & \\
\hline \multirow{3}{*}{4.} & Walking around & \multirow{3}{*}{$\begin{array}{l}\text { Moving } \\
\text { around }\end{array}$} \\
\hline & Running around & \\
\hline & Walking around to patrol & \\
\hline \multirow{5}{*}{5 . } & $\begin{array}{l}\text { Walking toward a rack to } \\
\text { take toys }\end{array}$ & \multirow{5}{*}{$\begin{array}{l}\text { Walking } \\
\text { toward } \\
\text { furniture }\end{array}$} \\
\hline & Walking toward toy rack & \\
\hline & $\begin{array}{l}\text { Walking toward rack to put } \\
\text { creation }\end{array}$ & \\
\hline & $\begin{array}{l}\text { Walking toward picture } \\
\text { board }\end{array}$ & \\
\hline & $\begin{array}{l}\text { Walking toward door to look } \\
\text { out }\end{array}$ & \\
\hline \multirow{3}{*}{6.} & $\begin{array}{l}\text { Walking toward other student } \\
\text { to play together }\end{array}$ & \multirow{3}{*}{$\begin{array}{l}\text { Moving } \\
\text { toward other } \\
\text { student }\end{array}$} \\
\hline & $\begin{array}{l}\text { Playing war game with other } \\
\text { student }\end{array}$ & \\
\hline & $\begin{array}{l}\text { Walking to follow other } \\
\text { student }\end{array}$ & \\
\hline \multirow{3}{*}{7.} & Walking toward teacher & \multirow{3}{*}{$\begin{array}{l}\text { Walking } \\
\text { toward } \\
\text { teacher }\end{array}$} \\
\hline & $\begin{array}{l}\text { Walking toward teacher to } \\
\text { show their creations }\end{array}$ & \\
\hline & $\begin{array}{l}\text { Walking toward teacher to } \\
\text { ask something }\end{array}$ & \\
\hline \multirow[b]{2}{*}{8.} & Walking and carrying a chair & \multirow{2}{*}{$\begin{array}{l}\text { Walking and } \\
\text { carrying } \\
\text { something }\end{array}$} \\
\hline & $\begin{array}{l}\text { Walking and carrying } \\
\text { paintbrush }\end{array}$ & \\
\hline
\end{tabular}




\begin{tabular}{|c|c|c|}
\hline Case & $\begin{array}{l}\text { In Game Setting } \\
\text { (Minutes) }\end{array}$ & $\begin{array}{l}\text { Outside Game } \\
\text { Setting (Minutes) }\end{array}$ \\
\hline K1 (F) & 40 & 20 \\
\hline K2 (M) & 14 & 46 \\
\hline $\mathrm{K} 3(\mathrm{~F})$ & 39 & 21 \\
\hline K4 (M) & 30 & 30 \\
\hline K5(M) & 31 & 29 \\
\hline K6 (F) & 37 & 23 \\
\hline K7 (M) & 15 & 45 \\
\hline K8 (M) & 42 & 18 \\
\hline K9 (F) & 45 & 15 \\
\hline K10 (M) & 38 & 22 \\
\hline K11 (F) & 46 & 14 \\
\hline \multirow[t]{2}{*}{$\mathrm{K} 12(\mathrm{M})$} & 48 & 12 \\
\hline & 425 & 295 \\
\hline
\end{tabular}

Duration of students in activity setting reached $59 \%$, outside activity setting reached $41 \%$. Children activities that were outside activity setting related to interview with teachers that playgroup students were easily bored. Concentration of children have not been able to focus in long time duration. It indicates that age affects children motion space.

Female students tend to stay longer in activity setting than male students. Average duration of male students outside activity setting tend to be longer than female students. Sex of children affects children motion space.

According to interviews with teachers, some reasons of children outside activity setting are: bored, uninterested with activities that teachers prepare, interested with something outside setting, following his friends, disliking his friends, embarrassed by feeling inadequate, observing how to play in activity setting, watching friends from distance, tired, and thirsty. It affects effective time standard (60 minutes) that should be in activity setting to be reduced. It will be one of the ineffectual factors of application BCCT curriculum.

\section{Conclusion}

Classroom settings in Playgroup Ratnaningsih use center system where in one center consists of some activity settings. Implementation of center system is moving class. There are some kinds of movements created by children in center: moving toward activity setting, moving toward furniture, moving toward friend or teacher, moving with bring objects, and circling that is not clear purpose.

Playgroup students spatially do not hold out in activity setting because they are easily bored with an activity provided by teachers in settings, children tend to move more frequently to other position. Concentrations of children have not been able to focus in duration for long time, children motion that is not clear purpose.

External factors also affect children motion space that causes children outside activity setting such as: elements of space, role of teachers, and design of activity settings they are not attractive for children. It affects effective time standard (60 minutes) that should be in activity setting to be reduced, so that learning becomes not effective maximum.

\section{References}

[1] Anonim, 2005, Kamus Besar Bahasa Indonesia, Edisi Ketiga, Pusat Bahasa Departemen Pendidikan Nasional, Balai Pustaka, Jakarta.

[2] Departemen Pendidikan Nasional, 2009, Pedoman Penerapan Pendekatan Beyond Centers and Circle Time (BCCT) (Pendekatan Sentra dan Lingkaran) dalam Pendidikan Anak Usia Dini, Jakarta.

[3] Handoko, Dipo, 2008, Mengajar Dengan Sentra dan Lingkaran, http://www.penapendidikan.com/mengajardengan-sentra-dan-lingkaran.html

[4] Harizal, 2008, Implementasi Konsep Montessori Pada Pendidikan Anak Usia Dini, 
International Journal of Built Environment and Scientific Research p-issn: 2581-1347 | e-issn: 2580-2607 | Pg. 117 - 130

http://www.jugaguru.com/column/21/tahun/2008/bulan/ 12/tanggal/19/id/849

[5] Haryadi dan Setiawan, B, 1995, Arsitektur Lingkungan dan Perilaku, Proyek Pengembangan Pusat Studi Lingkungan, Direktorat Jendral Pendidikan Tinggi Departemen Pendidikan dan Kebudayaan Republik Indonesia.

[6] Purwaningrum, Lu'lu', 2006, Studi Ruang Gerak (Place Ballet) Anak Usia TK B pada Tiga Tipe Kelas yang Berbeda di Surakarta, Tesis S2 Teknik Arsitektur Universitas Gadjah Mada, Yogyakarta.

[7] Rapoport, Amos, 1982, The Meaning of The Built Environment, Sage Publication, Beverly Hills California.

[8] Seamon, David, 1979, A Geography of The Life World, St. Martin's Press, New York. 